\title{
T Waves Biphasic by ECG Finding
}

National Cancer Institute

\section{Source}

National Cancer Institute. I Waves Biphasic by ECG Finding. NCI Thesaurus. Code

C71087.

An electrocardiog raphic finding of a T wave with both positive and neg ative components.

$(\mathrm{CDISC})$ 